\title{
Extract of Dragon Fruit Pulp (Hylocereus polyrhizus) Potentially Stain Chromosomes of Red Onion (Allium ascalonicum)
}

\author{
GENESISKA $^{1}$, HERDA PRATIWI ${ }^{1}$ \\ ${ }^{1}$ Department of Agrotechnology, Faculty of Agriculture, Universitas Muhammadiyah Yogyakarta \\ Jl. Brawijaya, Tamantirto, Kasihan, Bantul, Daerah Istimewa Yogyakarta. 55183 \\ Email: genesiska@umy.ac.id
}

Received 10 May 2018; Received in revised form 24 May 2018;

Accepted 27 June 2018; Available online 26 November 2018

\begin{abstract}
Side effect of aceto-orcein as a dye of chromosome structures remains some risks. This dye may remain tissue damage on eyes mucous membrane, burnt by skin contact, severe irritation of respiratory by spray mist. Exploration of natural dye is an alternative solution. Betacyanine of red dragon fruits Hylocereus polyrhizus pulp might have a potential role to stain chromosome. Aim of this study is to extract dragon fruit pulp to stain chromosomes of mitotic cells of red onion Allium ascalonicum. The method used in this research is qualitative description of application squash method with aceto-orcein as synthetic dye and two ratio of extract ratio of red dragon fruits pulps as natural dye to mitotic cells of red onion roots. The result revealed that 2:1 ratio of red dragon fruits and distilled water could stain chromosomes of red onion somatic cells. Further specific solvent is required to further investigation to get best betacyanine extract of red dragon fruits pulps.
\end{abstract}

Keywords: betacyanine, chromosome, dragon fruit pulp, natural dye, staining

\section{INTRODUCTION}

In plant breeding, study of chromosomes morphology is an important key to identify plant species. Karyotype is a tool to determine plant species by discovery of the specific numbers of chromosomes. Karyotype data will be analyzed quantitatively using multivariate analysis techniques, which provide systematic position of species. Distinguish quantitative traits of chromosomes morphology of subgenus Vicia species (Gianfranco et al., 2008; Lysak et al., 2001).

A stain-fixative method for that study of chromosomes structures was found called aceto-orcein. Standard solution of this stain contains $45 \%$ of acetic and $1 \%$ of orcein. Staining root tip could be used successfully by using aceto-orcein with addition of 1 to $10 \mathrm{~mL}$ of $\mathrm{HCl}$ solution, and heating of the tissues (Cour, 2009; Maluszynska, 2003).

For plants, a preparation called squash method combined with dye of aceto-orcein could observe chromosome structures (Anjali et al., 2012; Pan et al., 2008). Meanwhile, side effect of aceto-orcein as a dye remains some risks. This dye may remain tissue damage on eyes mucous membrane, burnt by skin contact, severe irritation of respiratory by spray mist
(Elgubbi and Asayh, 2007; MCCSD, 2009). Therefore, safety of researchers who works in the squashing method with aceto-orcein is required an attention.

Exploration of natural dye is an alternative solution. Extraction of plant organ could be the material of natural dye (Elgubbi and Asayh, 2007; Gilbert and Cooke, 2001; Kasiri and Safapour, 2015). Some example of major categories of plant pigments are betalain, anthocyanin, carotenoids, and chlorophylls (Tanaka et al., 2008). Hylocereus polyrhizus commonly called dragon fruit or pitaya originated from Latin America is a member of Cactaceae family. Special characteristics of this deep color pulp fruit could be discovered in European, United States market and Asia such as Vietnam, Malaysia, Taiwan, and China. The color pulp is nitrogen-containing pigments (Rebecca et al., 2010). Red dragon pulp contains of betacyanine fractions, which highly reduce radical scavenging capacities (Tenore et al., 2012). This pulp extract exhibits the maximum peak at 230 and $537 \mathrm{~nm}$ which indicates presence of betalain compound. The result reveals the compound which responsible for purple appearance is betacyanine (Woo et al., 2011). This betacyanine might have a 
potential role to substitute aceto-orcein as synthetic dye. According to study of karyotype, Ramesh (2015) stated that Genus Allium is generally interesting karyotypic object for microscopy because of large genomes in medium size of chromosome and polyploidy. Therefore, aim of this study is to extract of dragon fruit pulp (Hylocereus polyrhizus) and used it to stain chromosomes of mitotic cells of red onion Allium ascalonicum.

\section{METHOD}

This research was conducted at Laboratory of Biochemistry, Faculty of Agriculture, Universitas Muhammadiyah Yogyakarta. The method used in this research is qualitative description by using squash method with aceto-orcein as synthetic dye and two ratio of natural dye from red dragon fruits pulps.

Extraction of dragon fruits pulps. Dragon fruits (Hylocereus polyrhizus) were used for material of extraction when reaching full ripening stage, i.e. 30-35 days after pollination. The pulp was separated from the skin using a stainless, then cut off the pulp into smaller. Direct extraction of pulp was by homogenization using a blender with different volume of distilled water as a solvent. There were 2 ratio of extraction process based on ratio of pulp weight (gr) and volume of $\mathrm{ddH}_{2} \mathrm{O}$ $(\mathrm{mL})$. Ratio A was 2:1 (w/v) which ratio of pulp weight (200 gr) and volume of distilled water $(100 \mathrm{~mL})$. Ratio B was 1:1 (w/v) which ratio of pulp weight (100 gr) and volume of distilled water $(100 \mathrm{~mL})$. Then, extraction result of dragon fruit pulps was filtered using $150 \mathrm{~mm}$ qualitative filter paper.
Chromosomes visualization of red onion (Allium ascalonicum). Preparation of chromosomes visualization of red onion used Squash method. First, somatic cells of the root were collected by cutting $0.5 \mathrm{~cm}$ of root tip to upper roots. This collection was conducted at 08.00 to 12.00 A.M to reach best mitotic time. The roots were fixated in $45 \%$ of glacial acetic acid $(45 \mathrm{ml}$ glacial acetic acid in $55 \mathrm{ml}$ of distilled water) at $4^{\circ} \mathrm{C}$ for 15 minutes and washed gently with distilled water in three times. Then, the roots were processed to maceration process in $1 \mathrm{~N}$ of Hydrochloride acid $\left(5 \mathrm{ml} \mathrm{HCl}\right.$ in $55 \mathrm{ml}$ distilled water) at $55^{\circ} \mathrm{C}$ for 15 minutes and washed until three times using distilled water. Staining process conducted by using ratio $\mathrm{A}$ and $\mathrm{B}$ which mentioned previous paragraphs, and positive control of $1 \%$ aceto-orcein conducted for 24 hours. Squash method with $1 \%$ of aceto-orcein dye was used in this research as a positive control. One percent of aceto-orcein was mixture of 1 gram of orcein in $100 \mathrm{ml}$ of $45 \%$ acetic glacial acid. Stained roots were put into slide glass and treated by glycerin before glass covering. Squashing by wooden sticks was conducted on the glass into form of single layer cells. Then, fixed specimens were observed using digital microscopy for reach best visual of chromosomes.

\section{RESULT}

In this research, application of natural dye from simple extraction of red dragon fruits peels to somatic cells of red onions roots was done. Two ratios of extracted pulps and control as dyes revealed image of the chromosome staining which presented in Figure 1.

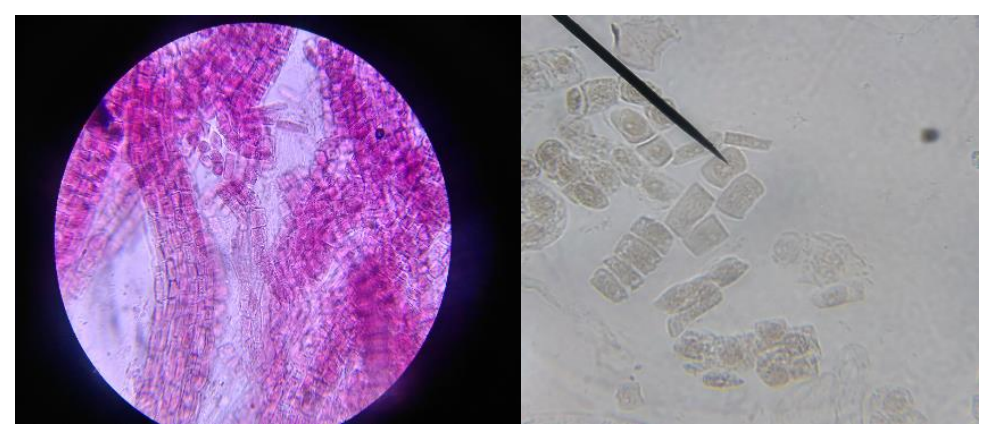

A
B

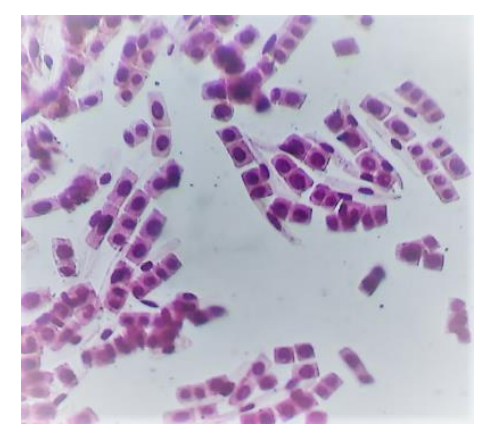

C 
Figure 1. Image of stained chromosome of red onions Allium ascalonicum with different ratio of natural dye using 40x magnification: A. Stained chromosome of mitotic cells by squashing method with Ratio A contains 2:1 (w/v); B. Stained chromosome of mitotic cells by squashing method with Ratio B contains 1: 1(w/v); C. Red stained chromosome of the mitotic cells by squashing method with $1 \%$ of aceto-orcein as positive control.

\section{DISCUSSION}

Staining chromosomes usually is utilized to make contrast between different cellular components then allow appropriate visualization with different capturing technique. In order to study of banding to chromosome structure, it requires understanding of how stains or dyes bind to the chromosomes. A stain could bind to DNA by intercalation, minor groove or major groove binding or external binding which can either be covalent or noncovalent (Armitage, 2005; Karlsson et al., 2003; Muhlisyah dkk., 2014; Nafisi et al., 2007).

Mechanism of using aceto-orcein dye is interaction process of an acid $\mathrm{pH}$ and negative charged groups or possible interact hydrophobically with chromatin. It binds to histon proteins at chromatin and stains its structure. Nucleoli could not be stained with acetic orcein, in meanwhile the chromatins which could be stained at clear area (K et al., 2014).

According to Figure 1, three views reveal three different quality of stained chromosomes in red onions which used 40x of magnification of digital microscopes. Ratio A contains of 2:1 ratio (w/v) of red dragon fruit pulps and distilled water could produce reddish specimen of mitotic cells of Allium ascalonicum, although the stained chromosomes is not quite clear to determine the structures and numbers of chromosomes. In meanwhile, ratio $\mathrm{B}$ contains of 1:1 ratio (w/v) of red dragon fruit pulps and distilled water could only create different contrast between cells to cells. In meanwhile, the chromosomes clearly can be stained by using $1 \%$ aceto-orcein dye as positive control.

Ratio A contains of 2:1 ratio (w/v) of the pulps and distilled water could help creating some dots in the middle cells that nucleus containing chromosomes and some stage of mitotic phase could be found in that microscopic images. This phenomenon might be happened as binding modes of major grove binding. However, staining of those chromosomes remains blurring images of mitotic cells. Binding modes which depend interaction between stain and Deoxyribonucleic acid (DNA). Major grove binding happens with special characteristics. This binding is formed because of binding modes with the corresponding of hydrogen bonding interaction, the functional group of electronegative atoms such oxygen and nitrogen of the stain responsible for the interaction, and the DNA site where $\mathrm{H}$ donor and $\mathrm{H}$ acceptor of the base pairs (Armitage, 2005; Maheswari and Palaniandavar, 2004; Yan et al., 2000; Zipper et al., 2004).

In this research, image of Figure 1A might give explanation that functional group of electronegative atoms such nitrogen in the betacyanine of red dragon fruits could interact with the DNA site of chromosomes of Allium ascalonicum somatic cells. Based on (Rebecca et al., 2010) explained that betacyanine is nitrogen-containing pigments. This interaction called major grove binding which hydrogen interaction classified as noncovalent binding with DNA site where $\mathrm{H}$ donor and $\mathrm{H}$ acceptor of the base pairs. The H-donor sites of the base pairs are positions 6 of adenine, 4 of cytosine, and 2 of guanine while the $\mathrm{H}$-acceptor sites are positions 3 and 7 of adenine and guanine, and 2 of thymine (Asensio et al., 2003; Gorb et al., 2004).

In meanwhile, specimen in Figure 1A and $1 \mathrm{~B}$ could be stained in the surrounding of the nucleus and cell wall. It might because of acid part of red dragon fruits could stain base parts of nucleus and cell wall. Based on Nurwanti dkk. (2013), anthocyanin in the red dragon fruits which has low $\mathrm{pH}$ (acid condition) could stain cell walls where in the base condition. Therefore, further extraction by specific solvent for red dragon pulps need to investigate. 


\section{CONCLUSION}

Extraction of dragon fruit pulp (Hylocereus polyrhizus) potentially could stain chromosomes of mitotic cells of red onion Allium ascalonicum with ratio A contains 2:1 $(\mathrm{w} / \mathrm{v})$ of red dragon fruit pulps (gr) and distilled water (v). Specific solvent of red dragon fruit pulp is required to further investigation to get best betacyanine extract of red dragon fruits pulps.

\section{REFERENCES}

Anjali M, and Srivastava AK. 2012. Karyological studies in twelve accessions of Carthamus tinctoriusi. Caryologia. vol 65(1): $1-6$. https://doi.org/10.1080/00087114.2012.6 78072.

Armitage BA. 2005. Cyanine dye-DNA interactions: Intercalation, groove binding, and aggregation. Topics in Current Chemistry. vol 253: 55-76. https://doi.org/10.1007/b100442.

Asensio A, Kobko N, Dannenberg JJ. 2003. Cooperative hydrogen-bonding in adenine-thymine and guanine-cytosine base pairs. Density functional theory and møller-plesset molecular orbital study. Journal of Physical Chemistry A. vol 107(33): 6441-6443. https://doi.org/10.1021/jp0344646.

Cour LLa. 2009. Acettc-Orcein: A New StainFixative for Chromosomes. Stain Technology. vol 16(4): 169-174. https://doi.org/https://doi.org/10.3109/10 520294109107302.

Elgubbi H, and Asayh EA. 2007. Chromosome Staining with Natural Dyes from Punica granatum and Beta vulgaris. EC Nutrition. vol 11(4): 142-146.

Gianfranco V, Ravalli C, Cremonini R. 2008. The karyotype as a tool to identify plant species: Vicia species belonging to vicia subgenus. Caryologia. vol 61(3): 300319.https://doi.org/10.1080/00087114.20 08.10589642 .

Gilbert KG, and Cooke DT. 2001. Dyes from plants: Past usage, present understanding and potential. Plant Growth Regulation. vol 34(1): 57-69.
https://doi.org/10.1023/A:101337461887 0 .

Gorb L, Podolyan Y, Dziekonski P, Sokalski WA, Leszczynski J. 2004. Double-proton transfer in adenine-thymine and guaninecytosine base pairs. A post-Hartree-Fock ab initio study. Journal of the American Chemical Society. vol 126(32): 1011910129. https://doi.org/10.1021/ja049155n.

K, HP, Lunggani AT, Nurhakim MA. 2014. Chromosomes and Mitotic Cell Division Phase in Onion Roots After 24 Hours Acetoorcein Soaking Time. Bioma. vol 2(46-48):

https://doi.org/https://doi.org/10.14710/bi oma.14.2.46-48.

Karlsson HJ, Eriksson M, Perzon E, Åkerman B, Lincoln P, Westman G. 2003. Groovebinding unsymmetrical cyanine dyes for staining of DNA: Syntheses and characterization of the DNA-binding. Nucleic Acids Research. vol 31(21): 6227-6234.

https://doi.org/10.1093/nar/gkg821.

Kasiri MB, and Safapour S. 2015. Exploring and Exploiting Plants Extracts as the Natural Dyes/Antimicrobials in Textiles Processing. Progress in Color, Colorants and Coatings. vol 8: 87-114.

Lysak MA, Fransz PF, Ali HBM, Schubert I. 2001. Chromosome painting in Arabidopsis thaliana. Plant Journal. vol 28(6): 689-697. https://doi.org/10.1046/j.1365313x.2001.01194.x.

Maheswari PU, and Palaniandavar M. 2004. DNA binding and cleavage properties of certain tetrammine ruthenium(II) complexes of modified 1,10phenanthrolines-Effect of hydrogenbonding on DNA-binding affinity. Journal of Inorganic Biochemistry. vol 98(2):

219-230. https://doi.org/10.1016/j.jinorgbio.2003.0 9.003.

Maluszynska J. 2003. Cytogenetic tests for ploidy level analyses-chromosome counting. Doubled Haploid Production in Crop Plants. Dordrecht: Springer. 
https://doi.org/10.1007/978-94-017-12934_51.

MCCSD. 2009. Aceto-Orcein Solution, $2 \%$. New York: Middle Country Central School District.

Muhlisyah N, Muthiadin C, Wahidah BF, Aziz, IR. 2014. Preparasi Kromosom Fase Mitosis Markisa Ungu (Passiflora edulis) Varietas Edulis Sulawesi Selatan. Biogenesis: Jurnal Ilmiah Biologi. vol 2(1): $48-55$. https://doi.org/https://doi.org/10.24252/bi o.v2i1.467.

Nafisi S, Saboury AA, Keramat N, Neault JF, Tajmir-Riahi HA. 2007. Stability and structural features of DNA intercalation with ethidium bromide, acridine orange and methylene blue. Journal of Molecular Structure. vol 827(1-3): 35-43. https://doi.org/10.1016/j.molstruc.2006.0 5.004 .

Nurwanti M, Budiono JD, P RP. 2013. Pemanfaatan Filtrat Daun Muda Jati Sebagai Bahan Pewarna Alternatif Dalam Pembuatan Preparat Jaringan Tumbuhan. BioEdu. vol 2(1): 73-76.

Pan Y, Shi S, Gong X, Kuroda C. 2008. A natural hybrid between Ligularia paradoxa and L. duciformis (Asteraceae, Senecioneae) from Yunnan, China. Annals of the Missouri Botanical Garden. vol 95(3): 487-494. Retrieved from https://www.jstor.org/stable/25488207.

Ramesh A. 2015. Karyotypic analysis in three species of Allium and their some Varieties. International Research Journal of Biological Sciences. vol 4(9): 1-9.

Rebecca OPS, Boyce AN, Chandran S. 2010. Pigment identification and antioxidant properties of red dragon fruit (Hylocereus polyrhizus). African Journal of Biotechnology. vol 9(10): 1450-1454. https://doi.org/10.5897/AJB09.1603.

Tanaka Y, Sasaki N, Ohmiya A. 2008. Biosynthesis of plant pigments: Anthocyanins, betalains and carotenoids. Plant Journal. vol 54(4): 733-749. https://doi.org/10.1111/j.1365313X.2008.03447.x.

Tenore GC, Novellino E, Basile A. 2012. Nutraceutical potential and antioxidant benefits of red pitaya (Hylocereus polyrhizus) extracts. Journal of Functional Foods. vol 4(1): 129-136. https://doi.org/10.1016/j.jff.2011.09.003.

Woo KK, Ngou FH, Ngo LS, Soong WK, Tang PY. 2011. Stability of betalain pigment from red dragon fruit (Hylocereus polyrhizus). American Journal of Food Technology. vol 6(2): 140-148. https://doi.org/10.3923/ajft.2011.140.148.

Yan X, Habbersett RC, Cordek JM, Nolan JP, Yoshida TM, Jett JH, Marrone BL. 2000. Development of a mechanism-based, DNA staining protocol using SYTOX orange nucleic acid stain and DNA fragment sizing flow cytometry. Analytical Biochemistry. vol 286(1): 138148.

https://doi.org/10.1006/abio.2000.4789.

Zipper H, Brunner H, Bernhagen J, Vitzthum F. 2004. Investigations on DNA intercalation and surface binding by SYBR Green I, its structure determination and methodological implications. Nucleic Acids Research. vol 32(12): 1-10. https://doi.org/10.1093/nar/gnh101. 